\title{
State, City, Commerce: The Case OF Bima*
}

\author{
Henri Chambert-Loir
}

On the map of the Lesser Sunda Islands, between Bali and Lombok in the west and Flores, Sumba, and Timor in the east, lies the island of Sumbawa, a compact, homogenous fief of Islam in the midst of a religious mosaic, of which history has not yet finished modifying the pattern. From west to east the island, which forms part of the Nusa Tenggara province, is divided into three kabupaten : Sumbawa, Dompu, and Bima. Today the latter contains almost 430,000 inhabitants, ${ }^{1}$ of whom probably 75,000 live in the twin agglomerations of Bima and Raba.

\section{The Present Town}

The Raba quarter developed at the beginning of this century when the kingdom of Bima was integrated into the Netherlands Indies. It contains the main administrative buildings: the offices of the bupati, located in the for mer house of the Assistant-Resident, the regional parliament (DPRD), and the local headquarters of the various administrative services. The urban center remains that of the former capital of the sultanate, in the vicinity of the bay. In contrast to the governmental pole concentrated in Raba, the agglomeration of Bima contains the main centers of social life, both past and present. The former palace of the Sultans $\left(\mathrm{N}^{\circ} 4\right.$ on Fig. 2) is an imposing masonry edifice built at the beginnirig of this century. Today it is practically deserted and will probably be converted into a museum. West of the palace there is a large rectangular square, to the south of which still stands the small mosque which in the last century the Sultan attended every Friday. The large mosque, which is of recent construction, is situated to the northwest of the palace. The market and the commercial area, which naturally constitute the hub of the most animated activity, are located in the direction of the bay, in the area of Kampung Tanjung and Sarae.

\footnotetext{
* The French version of this article appeared in Archipel 37 (1989): 83-105.

${ }^{1}$ Figure estimated for 1988 based on the 1980 Census ( 366,740 inhabitants, annual growth rate of 2.1 percent). The very approximative estimate of the population of Bima and Raba is based on that of the kecamatan Rasanae (ca. 100,000 inhabitants in 1988), where at least 11 of the 25 desa constituted the urban zone (see Penduduk Indonesia 1980 menurut Propinsi dan Kabupaten/Kotamadya. Hasil pencacahan lengkap Sensus Penduduk 1980 (Jakarta: Biro Pusat Statistik, 1981), Peta Index Kecamatan dan Desa/Kelurahan di Propinsi Nusa Tenggara Barat. Hasil pemetaan Sensus Penduduk 1980 (Jakarta: Biro Pusat Statistik, 1982), and Kabupaten Bima dalam angka, tahun 1981 (Bima: Kantor Statistik, 1982).
} 


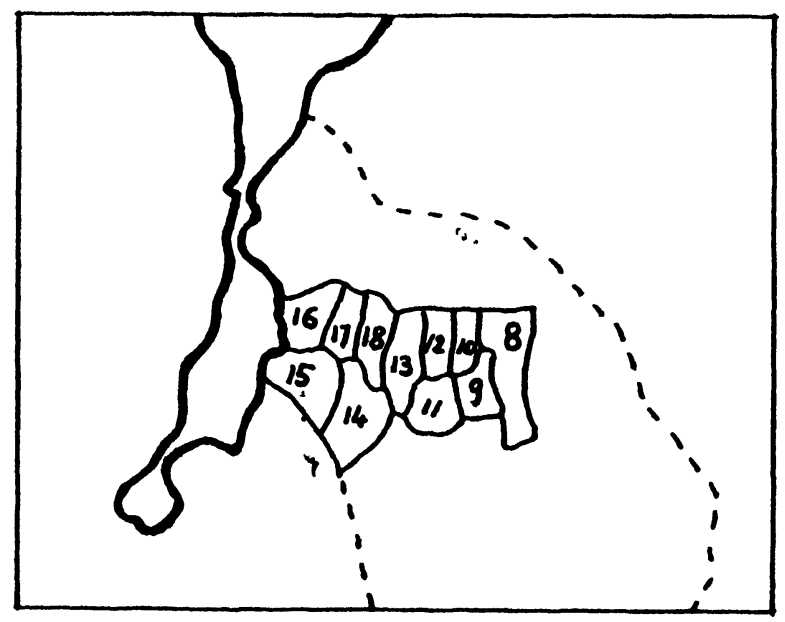

Fig. 1. The agglomeration of Bima and Raba. Map of the 11 urban kecamatan according to the official indexation. 8. Raba; 9. Rabangodu; 10. Penaraga; 11. Sadia; 12. Penatoi; 13. Menggonao; 14. Paruga; 15. Tanjung; 16. Melayu; 17. Sarae; 18. Nae (source: Peta Index 1980).

Two rivers wind their way through the town. Crossing over the Kali Bageroso, proceeding northwards from the market, one enters the kelurahan Melayu, where the three districts frequently mentioned by early travelers are to be found: first there is Kampung Benteng, the eastern part of the former Kampung Walanda where not a trace remains of the former Dutch fort and where the small, poorly maintained Christian cemetery seems to contain only 20th century graves; then comes Kampung Soro or Bugis; and finally Kampung Melayu, which, tradition has it, was given in the 17th century by the second Sultan of Bima (Abdu'l Khair Sirajuddin) to "Malays" entrusted with the propagation and control of Muslim orthodoxy. This part was formerly that of the foreign community: Malays, Bugis, Arabs, Chinese, and Dutch. Now foreigners of pure descent constitute no more than a few dozen families, while the peranakan and people of mixed race have been more or less integrated into the Bimanese population. For instance, today the Malays use Bimanese as their mother tongue.

Statistics from 1981 for the whole of the kecamatan Rasanae record 98.4 percent Muslims. ${ }^{2}$ Nevertheless, the registered places of worship comprise five churches and two Balinese temples, besides 66 mosques, 25 langgar, and 11 mushala.

A road leaves the town in a southerly direction, running alongside the Bay of Bima; it passes in front of the "heroes' cemetery" (makam pahlawan), continues on past the Chinese graveyard, which contains a hundred or so 20th century graves, and the small naval dockyard, before arriving at Palibelo Airport, which was renamed Muhammad Salahuddin, the name of the last Sultan, in 1983. Further on, at the southernmost end of the bay, for centuries saltworks have been producing salt, which today is exported to Java and Flores. The road continues to the west in the direction of Sila, Dompu, and Sumbawa Besar. Two other roads connect Bima with the east (Sape) and with the north (Wera).

The airport links Bima with Denpasar, Sumbawa Besar, and Waingapu. On average there are three small planes a day (1981). There is still a certain amount of activity in the harbor, especially as far as the export of cattle is concerned. However, the commercial wealth of

2 See Kabupaten Bima 1981. The remaining 1.6 percent consisted of 906 Christians, 322 Hindus, and 95 Buddhists. 
Bima ebbed away a long time ago. The export of foodstuffs has given way to imports; manufactured goods and crafts are of purely local interest and half the budget of the kabupaten is provided by subsidies from the province. In 1981, in the whole of the kabupaten, there were over 400 motor vehicles registered: 300 commercial vehicles, 96 motor coaches, and 10 private cars. The existence of several hotels may be a sign of a certain amount of activity, but they are rarely used and 79 tourists a year were registered (again in 1981).

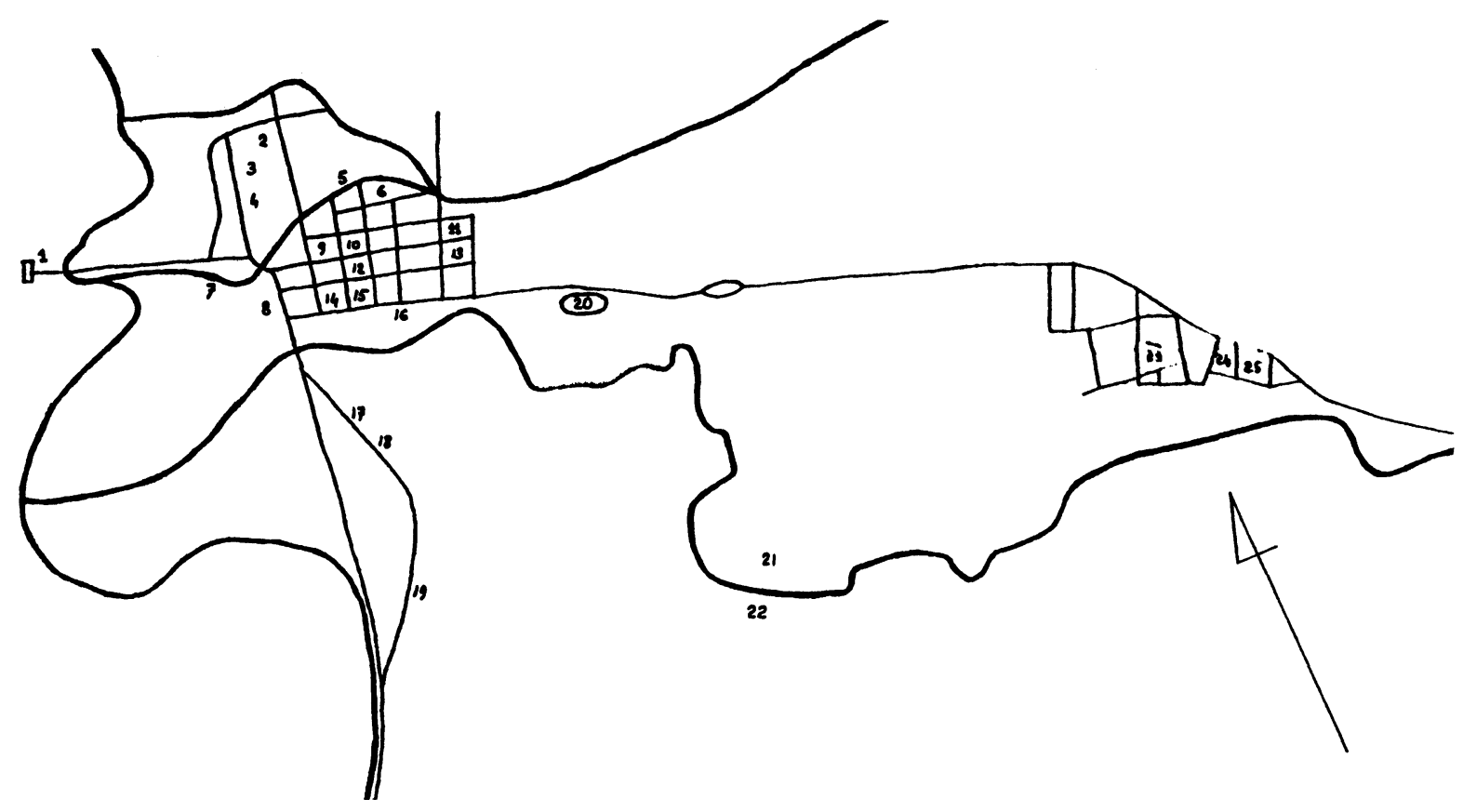

Fig. 2. The agglomeration of Bima and Raba. Schematic plan and toponyms (K. = Kampung). 1. The harbor; 2. K. Melayu; 3. K. Bugis or Soro; 4. K. Benteng; 5. Tolobali; 6. K. Gilipanda; 7. K. Tanjung; 8. K. Sumbawa; 9. K. Sarae; 10. K. Wera; 11. K. Nae; 12. Great mosque; 13. K. Pane; 14. Alun-alun; 15. The palace; 16 . K. Sigi; 17. K. Dara; 18. Heroes' cemetery (Makam Pahlawan); 19. Chinese cemetery; 20. Stade Manggemaci; 21. Dantaraha; 22. K. Sambinae; 23 \& 24. Main squares; 25. K. Raba Dompu.

In short, for today's visitors, the town of Bima seems a tranquil and small market town, which is hard to imagine as having once been the capital of a sultanate sufficiently powerful to dominate several of its neighbors as well as a center of commerce, frequented since time immemorial, and the home of an original culture.

\section{The Town in the 19th Century}

Travelers who visited Bima in the last century and committed their impressions to paper allow us to form an idea of the town while it was still the capital of an independent sultanate. It was a small town, whose population was estimated at 5,000 by Reinwardt in 1821 and at 7,000 by Braam Morris in 1891. ${ }^{3}$ The painting executed by A.J. Bik in 1821 (Fig. 3) shows a village with only a few scattered houses emerging from among the trees.

3 See C.G.C. Reinwardt, Reis naar het oostelijk gedeelte van den Indischen Archipel in het jaar 1821 (Amsterdam: Muller, 1858), p. 319, and D.F. van Braam Morris, "Nota van toelichting behoorende bij het contract gesloten met het landschap Bima op den 20sten Oct. 1886," TBG 34 (1891): 179. 


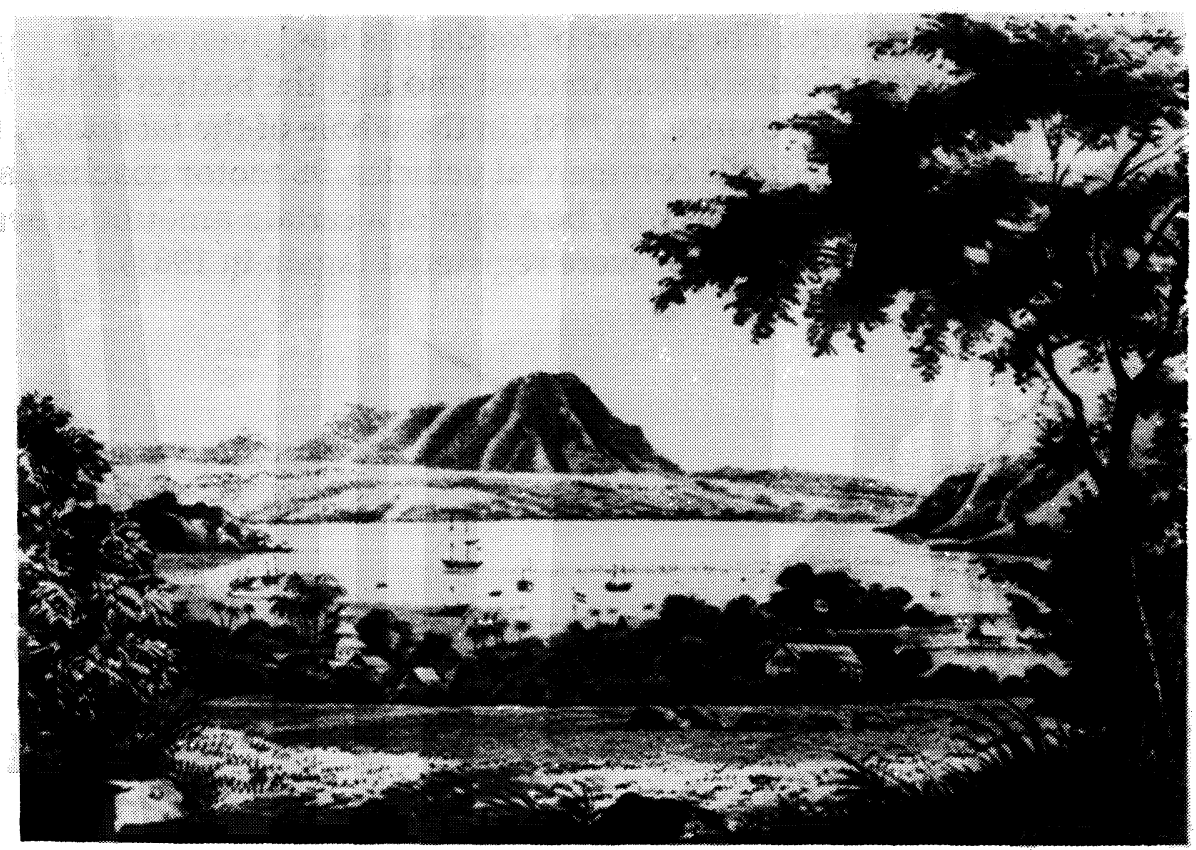

Fig. 3. The agglomeration and the Bay of Bima in 1821. Engraving by A.J. Bik, published in Reinwardt, Reis naar het oostelijk gedeelte. The mosque with the triple roof and the shallows, which made an approach difficult, are clearly visible. The flag in the center probably marks the site of the Dutch fort.

"There are absolutely no stone buildings. All the bricks for the residence of the Sultan and the mosque came from Java," Zollinger noted during his visit in $1847.4 \mathrm{He}$ added: "The Sultan and the population have not yet summoned up the energy to construct a bridge for pedestrians. When one wishes to visit the Sultan [from the Dutch residency], it is necessary to ford the small river, or have oneself carried across." 5

The palace itself was a wooden building. The present palace (Bim. Asi Wadu, meaning istana batu, "the stone palace") was, it seems, built in the 1920s. Formerly it was a wooden edifice, with an entrance stairway in masonry (see Fig. 4). The previous palace (Asi Bou, istana baru, "the new palace"), which was situated to the east of it, was a considerably smaller building and was constructed entirely of wood. It seems to have been started by Sultan Abdul Hamid in 1781.6 When Rouffaer visited Bima in 1910 this palace, already relegated to second place, was the residence of the crown prince, the Raja Muda. ${ }^{7}$ Both these palaces

The Encyclopaedie van Nederlandsch-Indië ( 8 vols. [2nd ed. Leiden/The Hague, 1917-1940]), in 1917 cites the figure of 10,000 inhabitants, which was already adjusted to 12,000 in the first supplement (1927).

${ }^{4} \mathrm{H}$. Zollinger, Verslag van eene reis naar Bima en Soembawa ... gedurende de maanden Mei tot December 1847. VBG [Batavia], 23 (1850): 98.

5 Ibid.

6 The manuscript journal of Moh. Djafar gives the date of the installation of the Sultan and his consort in the istana baru as Safar 19, 1195, i.e. February 14, 1781. (See the manuscript of the Benteng Ujungpandang: Lontara No. 152. Journal in Malay for the years 1775-1790 belonging to Muh. Djafar, Rato Rasanae.) However, the dates in this document must be treated with caution.

7 J. Noorduyn, Bima en Sumbawa. Bijdragen tot de geschiedenis van de Sultanaten Bima en Sumbawa door A. Ligtvoet en G.P. Rouffaer (Holland-USA: Foris, 1987), p. 75 
were surrounded either by a wooden fence or by a stone wall. ${ }^{8}$ Today all traces of these earlier palaces have disappeared.

The present palace, just as the former wooden one on the site of which it was erected, faces north. However, it is flanked on the eastern and western sides by two large squares. The palisades of the palace open onto the western alun-alun by means of a tiered monumental gateway built on an octagonal plan called the uma lare-lare. This once served as the entrance for court dignitaries and royal servants, and it was also from this that the Sultan showed himself to the people during the four days of the Maulud festival. ${ }^{9}$ At the top of this tower-like construction were hanging "several bells which proclaim the grandeur of the

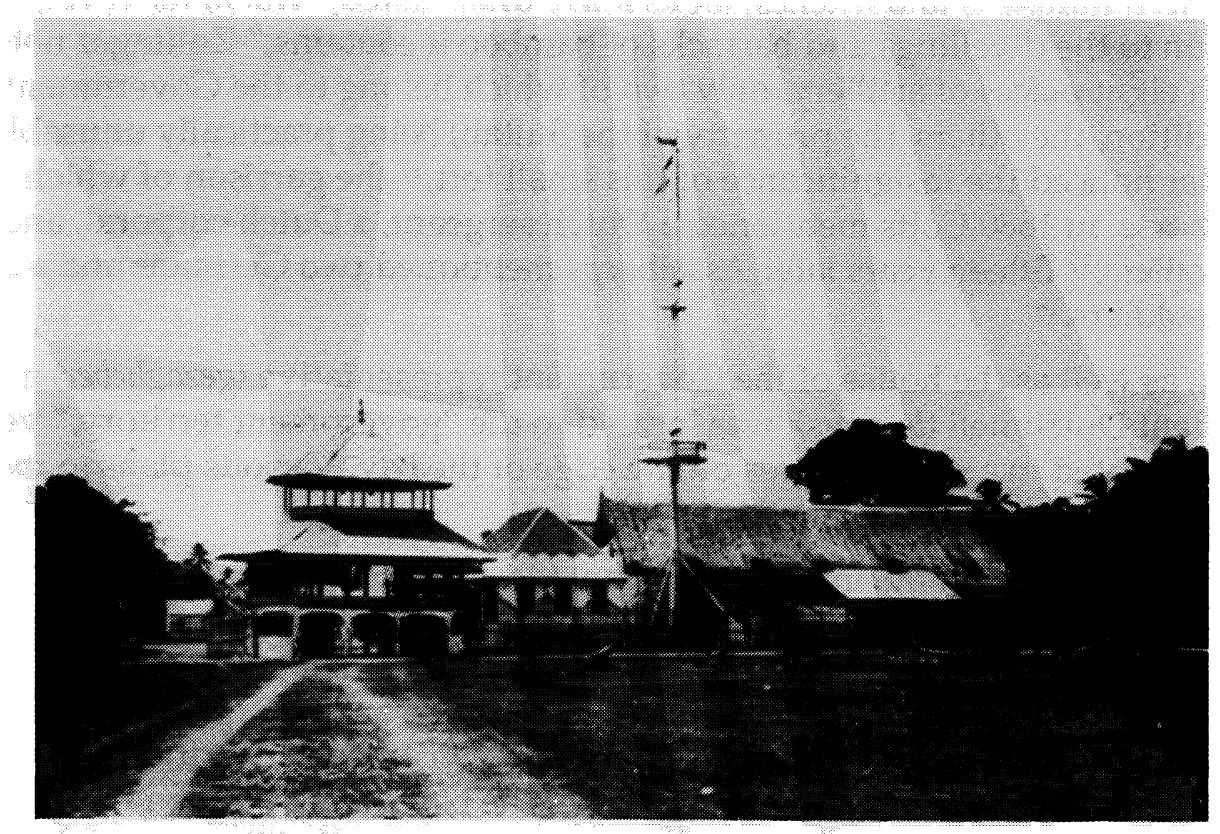

Fig. 4. The palace of Bima at the beginning of the century. One can make out a row of cannon along the edge of the alun-alun, two bells inside the monumental gateway (uma lare-lare) and the wooden palace to which has been joined a small masonry building. Collection of the KITLV in Leiden (Afd. DGI, doc. MR. 7411). By kind permission of the KITLV.

\footnotetext{
${ }^{8}$ The journal of Muh. Djafar notes on September 25, 1776: "Today a palisade has been erected around the palace of the sovereign." E. Francis in 1831, and Asselbergs in 1895, speak of a stone wall (E. Francis, Herinneringen uit den levensloop van een Indisch ambtenaar van 1815 tot 1851 Vol. 1 (Batavia: Van Dorp, 1856), p. 130; A. Asselbergs, "Eene reis naar het eiland Soembawa," Sint Claverbond I (1896): 63. Rouffaer, in his turn, describes the high wooden fence, apparently constructed in 1901, surrounding the later palace. (Noorduyn, Bima en Sumbawa, p. 71).

${ }^{9}$ See Rouffaer in Noorduyn, Bima en Sumbawa, p. 71. There is a photograph of this gateway, dating from the beginning of this century, in Fig. 4, and another, taken in 1976, in H. Chambert-Loir, Syair Kerajaan Bima Jakarta: EFEO, 1982), p. 125.
} 
prince with their metal tongues." 10 In 1910 on the western alun-alun stood 13 cannons, including four made of Dutch bronze dating from the 17th and 18th centuries. ${ }^{11}$ To the south of the square stands the mosque with its three-storeyed roof which was constructed by Sultan Abdul Hamid in 1780.12

The residence of the Chief Minister (Raja Bicara) was a large wooden house situated at a place called Nteli (Kampung Nae), northeast of the palace. Zollinger, who was received there in 1847, accords it no more than a contemptuous note which, nevertheless, hints at a certain opulence: "The next day I paid a visit, with the same solemnity, to the radja bitjara, or governor. His house, even more than that of the Sultan, is encumbered with all sorts of objects. The interior gallery looks more like a toko than a reception hall for foreigners." 13 The ridgepole of this gallery was supported by three moulded pillars supposed to symbolize the three foundations of power: royal administration, Islamic law, and custom. ${ }^{14}$

Close to the shoreline, southwest of Kampung Walanda stood the Dutch fort. "The fort, with its earthern ramparts and ditches, looks fairly dilapidated, which, however, is nothing in comparison to the dwellings and barracks of bamboo it contains," Zollinger notes. It was "armed with eight pieces of artillery, only two of which belong to the Government and are in good condition, the others, the property of the Sultan, being practically unusable."15 Every traveler noticed the insignificance of this small fort, ${ }^{16}$ the garrison of which was also extremely sparse: in 1880 Colfs mentioned a Dutch sergeant, a Dutch corporal, and 15 indigenous fusiliers; ${ }^{17}$ fifteen years later Asselbergs mentioned two Germans and a dozen indigenous soldiers. ${ }^{18}$

This fort, as well as the house of the Government representative (gezagheber) and those of several resident Dutchmen (burgers), was located in the "government territory," very uncomfortably situated in a swampy area on the edge of the bay. Various plans to move them to a more salubrious area came to nothing. ${ }^{19}$

The location of Bima on the inner shore of a wide, deep bay offered ships a secure, sheltered anchorage. The approach was rendered difficult by the presence of a mudbank directly in front of the town itself, which made it impossible to tie up at a wharf and which sometimes had to be crossed on foot. Reinwardt, Zollinger, and Jasper are among those who suffered this experience. "It is a strange phenomenon," writes Reinwardt," "that the water can be so very deep everywhere right to the end of the bay so that one can find absolutely no anchorage at all and that very close to the shore we were still obliged to anchor at a

\footnotetext{
${ }^{10}$ Asselbergs, "Eene reis naar het eiland Soembawa," p. 63.

${ }^{11}$ See Rouffaer in Noorduyn, Bima en Sumbawa, pp. 71, 104.

12 Ibid., p. 87. The journal of Muh. Djafar mentions the stages of construction on December 10, 1778, and January 5 and A pril 25, 1779. It is the roof of this mosque which one sees on the drawing of A.J. Bik (Fig. 3).

13 Zollinger, Verslag van eene reis, p. 18.

${ }^{14}$ M. Hitchcock, "The Bimanese Kris: Aesthetics and Social Value," BKI 143, 1 (1987); 129.

15 Zollinger, Verslag van eene reis, p. 98.

16 See Rouffaer's remarks: "het kleine onbeduidende fort ... het onnoozele fortje," in Noorduyn, Bima en Sumbawa, p. 71.

17 A. Colfs, Het journaal van Albert Colfs. Eene bijdrage tot de kennis der Kleine Soenda-Eilanden, door A.G. Vorderman. (Batavia: Ernst \& Co, 1888), p. 45.

18 Asselbergs, "Eene reis naar het eiland Soembawa," p. 53.

19 J.E. Jasper, "Het eiland Soembawa en zijn bevolking," TBB 34 (1908): 79.

${ }^{20}$ Reis naar het oostelijk gedeelte, p. 314.
} 


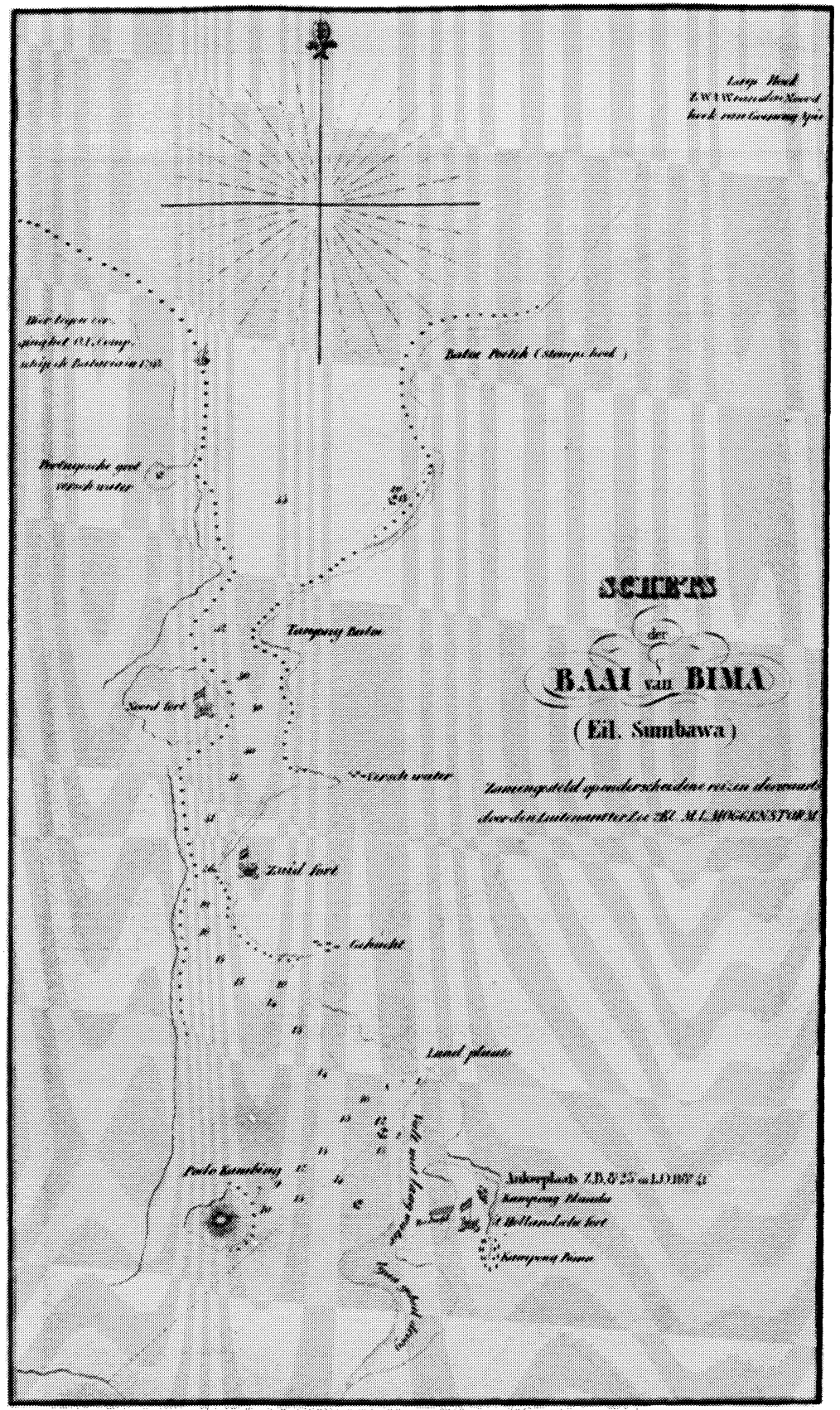

Fig. 5. Map of the Bay of Bima (undated). Marked are the sites of the two small forts and the "Portuguese cave," that is to say the site of Wadu Paa. Collection Algemeen Rijksarchief, The Hague, doc. MIKO 548. By kind permission of the Archives. 


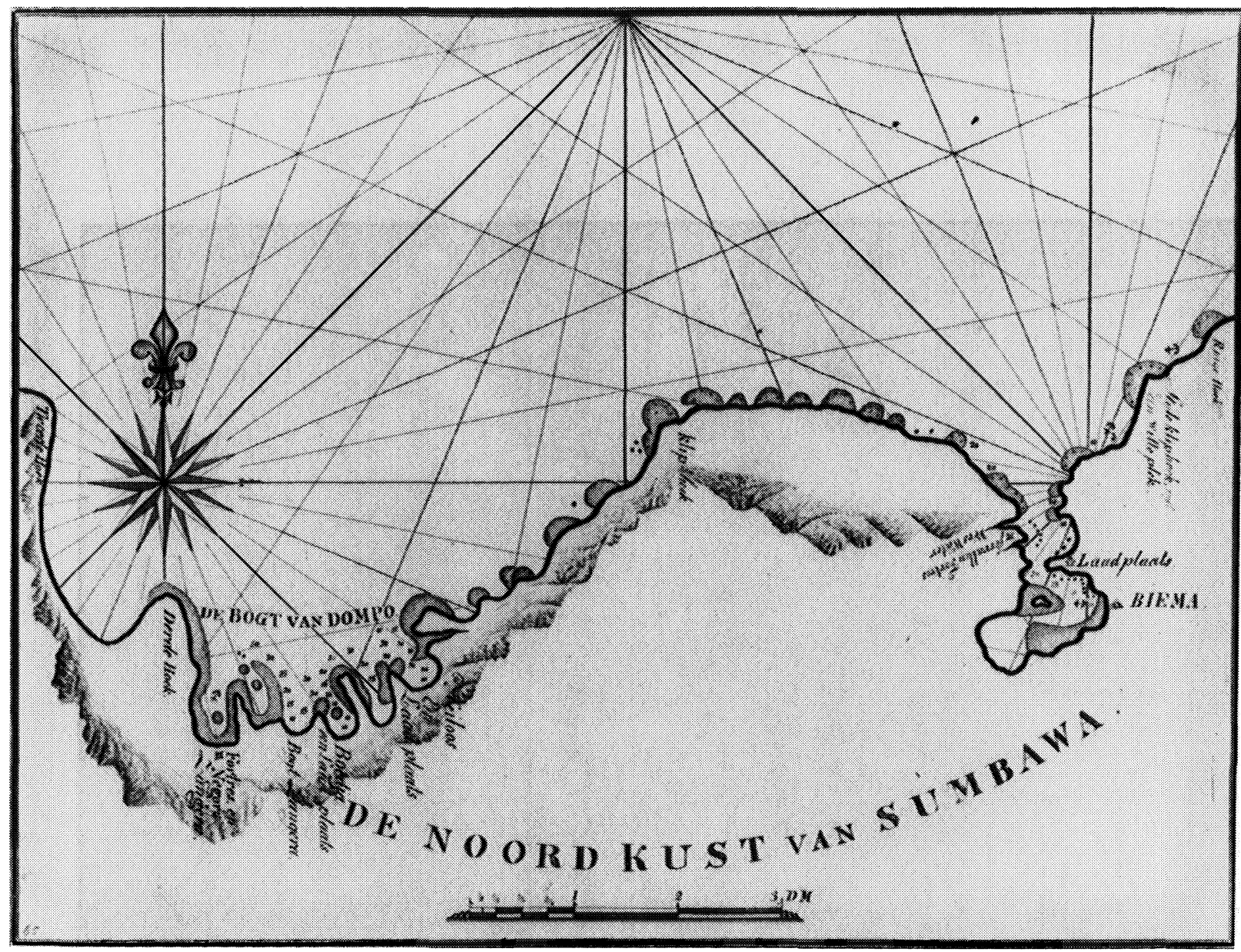

Fig. 6. The north coast of Sumbawa (undated). Collection Algemeen Rijksarchief, The Hague, doc. MIKO 65. By kind permission of the Archives. 
depth of 13 fathoms. Right in front of the town, at the edge of the bay, one encounters a deep mudbank which, especially at low tide, makes an approach very difficult, even with small craft (...). Therefore I was obliged to have myself carried over the mud, whereas my travelling companions had to resign themselves to crossing the thick mud on foot." Zollinger, who faced the same difficulties, surveyed the unloading of his baggage, which took four days, with alarm. He adds: "Up to the present time the Sultan has promised a hundred times that he would make the landing stage more accessible, which would not incur great difficulties, but he has not done anything about it. The sappan wood is loaded half an hour further to the north, where the approach is easier." 21

When steamships began to call at Bima the Dutch Government installed coal bunkers on the small island of Pulau Kambing which lies in the bay facing the town. ${ }^{22}$

The entrance of the Bay of Bima is easy to locate because of the presence of Mount Soromandi or Vadersmits close to the shore on the western side. The channel rapidly narrows to the point, quoting J.Th. Bik, "where, from on board, one can throw a pebble onto either bank." 23 This was the place where two small forts were constructed on either side of the bay, giving control of the mouth. One was built on a small promontory on the shore to the west of the bay: it was rectangular (ca. $150 \times 80 \mathrm{~m}$ ) with rounded bastions at each of the four corners. Its walls were six feet high. To the south of this fort lay the other one, which was slightly smaller (ca. $95 \times 60 \mathrm{~m}$ ), built on the eastern shore of the bay. Both were armed with cannon. ${ }^{24}$ Every traveler noted the military insignificance of these defenses and agreed in commenting that several pieces of artillery would be sufficient to prevent access to the bay. As Noorduyn notes, the construction of these forts must have taken place before the middle of the 17 th century. ${ }^{25}$

Even though they are of a late date and are fragmentary, these travelers' notes imbue the capital of the sultanate with the image of an agglomeration of very mediocre importance, at least as regards its size and its buildings: several hundred wooden houses, negligible fortifications, no monument worthy of the name, an open-air local market, a small port with difficult approaches.... It is even possible that in volume of commerce and population, at certain times, Bima did not surpass Sape, or even Wera or Kore.

\section{An Urban Society}

But Bima was not just an overgrown village which seemed insignificant to the eyes of visitors disembarking from Makassar or Batavia. The urban character of this capital, as indeed it was, does not lie in the number or nature of its buildings: it emerges when one

21 Zollinger, Verslag van eene reis, pp. 17, 18.

22 Jasper, "Het eiland Soembawa," p. 63, and B.F. Matthes ("Eenige opmerkingen omtrent en naar aanleiding van dat gedeelte van Dr. J.J. de Hollander's Handleiding bij de beoefening der Land- en Volkenkunde van Nederlandsch Oost-Indië, het welk handelt over het Gouvernement van Celebes en Onderhoorigheden," BKI 19 [1876]: 91) noted the presence of these fueling stations in the years 1850 and 1860 . Today no trace of them remains.

23 "Aanteekeningen nopens eene reis naar Bima ...," TBG 14 (1864): 126.

${ }^{24}$ See the maps in Figs. 5 and 6. The measurements are those given by Rouffaer (Noorduyn, Bima en Sumbawa, pp. 102-103), who also provides the plan of the two small forts and a photograph of the southern fort as it was in 1910. The two forts, although now complete ruins, are still visible at the present time, but all the cannon have been transported to Bima. The two forts together are known locally as Asa Kota, literally "the mouth of the town," an expression which the dictionary of A.K. Sahidu defines as "the port, the Bay of Bima."

25 Bima en Sumbawa, pp. 115n., 173. 
examines the composition of the population and the nature of its resources, the centralization of the symbols of power, the multiplicity of its external contacts, and its cultural and religious life. The example of Bima is certainly not a unique one of an agglomeration of which the urban character cannot be defined in terms of its physical characteristics (number of inhabitants, importance of buildings, presence of fortifications), but springs from the origin, the divisions, and occupations of the population. When a town is contrasted with a village this is not in terms of size but in the way of life. The ethnic diversity, the presence of a central power and its insignia, the concentration of economic activity and contacts with foreign nations all give rise to special types of apportionment of the area and density of settlement, to social stratification and the administration of individual obligations toward the community as a whole, to the proliferation of service activities, the development of the arts, the integration of foreign influences, and the recourse to the use of a lingua franca; such are the collective traits which define the urban phenomenon.

In this area even more than in others, the documents are incomplete and inconsistent, and one has to resort not only to foreign accounts but also to local sources, and this over a longer period. The origins of the kingdom of Bima stretch back to an unknown epoch. However, the advent of the sultanate dates from the conversion to Islam of the first Sultan, a matter on which Noorduyn has recently shed new light, the fruit of the cross-checking of a number of documents: ${ }^{26}$ the Islamization of Bima was the consequence of two military expeditions launched by Makassar in 1618 and 1619, which makes the date of the conversion of Sultan Abdul Kahir as it is given in a Bimanese document, namely February 7, 1621, plausible.

The political and economic situation of the sultanate was modified by contracts signed with Makassar and Bima by the VOC in 1667 and 1669. As a result, its prosperity diminished down the course of the centuries and it was also considerably weakened by the eruption of Mount Tambora in 1815. The absorption of Bima into the territory of the Netherlands Indies in 1905 marked a new phase in its history. In matters which concern the characteristic traits of the town, however, it does not seem that, from the beginning of the 17th century to the beginning of the 20th century, it should be necessary to distinguish different periods according to factual events.

Bimanese society made a categorical distinction between autochtonous people and foreigners. The Bimanese, who were drawn to the capital from all parts of the realm, were divided into two classes: the nobility, among whom the Ruma were distinguished from the Rato, and the "free men" (dou mardika), among whom two terms of address (uba and ama) effected a subdivision. Slaves fell outside Bimanese society. They came mainly from Manggarai and Sumba. 27

This hierarchy was superimposed on a horizontal division which unfortunately never attracted the attention of ethnologists; scattered references to it in several sources only give a very imprecise picture: the population was divided into groups (dari), which writers generally defined as "guilds" or "corporations," because one of their characteristics was the specified nature of the statutory labor each of them was expected to perform. Zollinger gives the name of 13 of them. Braam Morris and Jasper who copied the same source, probably the report of a local official-and both of whom lament identically about the "confused and more than once contradictory" information provided by the dignitaries of Bima-list

26 Ibid.

27 From a personal communication from A.M. Daeng Talu, born in 1911, who was the last Tureli Belo. 
respectively 43 and 42 of them. ${ }^{28}$ Jasper groups these under 13 headings, and this figure is mentioned too in volume 1 of the Encyclopaedie van Nederlandsch-Indië in 1917. However, in its first supplement (vol. 5, 1927), this was corrected to 70 on the basis of an unknown source.

On several occasions Zollinger mentions the under-chiefs (onder-chefs) but there does not seem to have been any sort of hierarchy in the dari, except that each of them was under the authority of a man of note bearing the title of Bumi or Anangguru. Some of them were not assigned to regal corvée, but were in the service of an important personage in order to assist him in his duties: the Dari Sabicara Kae, Luma Rasanae, and Luma Bolo were at the service of the Raja Bicara, the Bumi Luma Rasanae, and the Bumi Luma Bolo respectively. This seems to have involved a strict client system; however, the functions and duties of the dari were very complex.

On certain occasions and within certain limitations most of the dari were expected to provide precisely defined services for the palace or the State. The nobles of the Dari Ratu provided dancers and pages; members of the Dari Jara Mbojo and Jara Bolo, also aristocrats, formed the palace guard; three other dari furnished flautists, another wet nurses. Certain set tasks were assigned to the common people and did not require any real specialization: soldiers in time of war (Dari Suba Nae), the sailors of the Sultan and of the high dignitaries (Dari Pabise), the Sultan's grooms (Dari Jara), the cultivators of the Sultan's ricefields (Dari Tolotui); others required technical specializations and these merit the term guilds: carpenters, sculptors, blacksmiths (Dari Besi), goldsmiths (Dari Mas), fusiliers (Dari Bedi), doctors (Dari Cindawa), and men of religion (Dari Ngaji). Some of the dari escaped this classification as they contained persons from the various regions of the kingdom (people from Wera, Sangeang, Sape, or from the area south of the bay), or foreigners (Dari Parisi), or even people from all classes who were exempted from all statutory labor because of their merit (Dari Merdeka).

Membership of a dari was hereditary, but it did not actually impose any profession on the people: the Bimanese were free to exercise their talents without regard to the nature of the corvée imposed on their dari. In theory each dari was endogamous and cases of intermarriage were judged by the chiefs of the dari concerned, and involved the transfer of one of the spouses into the dari of his or her partner.

Finally this system also had a spatial consequence: first of all because each dari had the right to the yield from the harvest of the ricefields assigned to it. Second because each dari, or some of them at least, occupied a specific quarter of the town, the goldsmiths for instance lived in an area close to the northern gate in the wall of the palace fortifications. ${ }^{29}$

Therefore this social compartmentalization had manifold consequences: asserting ethnic integrity vis-à-vis the foreigners, concretizing the distinction between aristocrats and the common people, marking geographic origin, dividing the community in endogamous clans, assessing the civic duties, and alloting the social space.

Apart from the Bugis (under the authority of a matoa) and the "Malays" (under that of a penghulu), both of whom, as we have already seen, had their districts in the northwest part of the town, the foreigners consisted of Chinese, Arabs, and Europeans. These communities, whose history remains obscure, were never numerically important. There is mention of

28 Zollinger, Verslag van eene reis, pp. 132-33; Braam Morris, "Nota van toelichting," pp. 200-205; Jasper, "Het eiland Soembawa," pp. 106-108.

${ }^{29}$ Hitchcock, "The Bimanese Kris," p. 129. 
several dozen Chinese families in 1900, who also lived close to the shores of the bay. These were merchants and, in 1895, Asselbergs noted that in this rich country it was astonishing not to find rich Chinese, the reason behind this being probably the fact that these merchants were only the representatives of the large trading companies in Makassar. ${ }^{30}$ At the end of the last century the Arabs were probably more numerous. Specializing in the export of horses, they also played a religious role and more than one traveler records the ascendency that several Arabs appeared to enjoy at the palace. The European community was always extremely small but its presence went back to the 1680 s. $^{31}$ According to Zollinger, in 1846 , there were 14 Christian families, that is to say 59 people, upon whom 279 servants and slaves were dependent, in Kampung Walanda ("de governments-kampong").32

However, the contacts with the Europeans go back to an earlier time. The Dutch, whose first visit to Bima dated from the passage of the fleet of Steven van den Hagen in 1605, immediately found themselves in competition with the Portuguese. The latter regularly took on provisions in Bima; they sometimes built boats there; in 1618 they attempted to convert the king to Catholicism and, even after the contract of 1669 by which the VOC imposed its law on Bima, they occasionally continued to trade there. ${ }^{33}$

Less foreign within the ethnic and geographical framework of the Archipelago, but nevertheless external to the kingdom and people of Bima, were the inhabitants of Java, Bali, Banjar, Makassar, and the Moluccas with whom Bima maintained commercial and political relations. Sparse evidence for these contacts is deposited in the records of the palace of Bima. Several precise examples refer to the reign of Sultan Abdul Hamid (1773-1817): for instance, in May 1779 Javanese from Surabaya gave several wayang performances at the palace; between April and July 1787, a troupe, which had come from Batavia under the leadership of a khalipa, gave performances of dabus, some of which took place in the mosque: "they strike themselves and pierce themselves without being injured by either the iron or the stone." ${ }^{14}$ Much later, when Rouffaer visited Bima in 1910, a komedi stambul troupe was performing there. ${ }^{35}$

Sultan Abdul Hamid attended the wayang and dabus performances, just as he used to go along to the scene of popular feasts, notably a kind of wrestling (begoco): during a tourna-

30 Asselbergs, "Eene reis naar het eiland Soembawa," p. 59.

31 The Company considered a permanent settlement at Bima from 1675, but abandoned the idea. Generale Missiven van Gouverneurs-Generaal en Raden aan Heren XVII der Verenigde Oostindische Compagnie uitg. door W.Ph. Coothaas. 8 vols. (The Hague: Nijhoff, 1960-1985), 4: 2-3. There is reference to a Resident of Bima from the year 1689 and the years thereafter (ibid., 5: 395, 455, etc.).

32 Zollinger, Verslag van eene reis, p. 101.

33 With reference to Portuguese trade with Bima see, for example, Noorduyn, Bima en Sumbawa, p. 331: about 1618 the Portuguese visited the north coast of Bima every year, in December or January, in order to load dye wood. The Dagh Register gehouden int casteel Batavia (1624-1682) (31 vols., Batavia/The Hague, 1886-1931) [hereafter Dagh Register], mentions (on September 21, 1631 and November 21, 1640) ships constructed for the Portuguese in Bima. Noorduyn published unedited documents on the attempted conversion of the King of Bima by the Jesuit Manuel Ferreira. Ibid., pp. 334-38. The complete original (Portuguese) text, accompanied by a summary and notes, of the letter from Father Manuel Barrada S.J. (November 20, 1619) relating the episode, has been published in H. Jacobs, S.J., ed., The Jesuit Makasar Documents (1615-1682) (Rome: Jesuit Historical Institute, 1988), pp.17-28. Finally, in 1673, "the King of Bima has conceded to the Portuguese, under the command of one Padre Brave, a whole quarter as their permanent residence, which runs absolutely contrary to the contract, because he tries to have his fortifications reinforced." (Generale Missiven 3: 845, letter of January 31, 1673). One may wonder whether this latter episode has any connection with the two forts on the bay, mentioned earlier.

34 Journal of Muh. Djafar.

35 Noorduyn, Bima en Sumbawa, pp. 76, 79. 
ment lasting more than a fortnight in October 1786, he gave a monetary reward to those protagonists who knocked down their opponents. ${ }^{36}$

The Sultan embodied the unity of the realm. The inhabitants of the town, as we have seen, were defined according to the duties which they had to perform for him; and many sites in the town mark either by monuments, toponyms, or simply by tradition, the landmarks of dynastic history, like so many symbols of the continuity of the authority which was centralized there.

To the east of the town, at a place which today is no longer certain, was the lake where the first king of Bima met the celestial nymph who was to give birth to the dynasty. ${ }^{37}$ The tomb of the first Sultan is located to the south at Dantaraha (N'25 on Fig.2); those of his three successors lie to the north at Tolobali $\left(N^{\circ} 11\right)$, while those of five other Sultans are right in the heart of the town in the courtyard of the mosque situated on the edge of the alun-alun $\left(\mathrm{N}^{\circ} 13\right)$. Also to the south of the town, on the hill of Mbanteli, lies buried the sacred horse: jara manggila, which is part of the royal insignia. ${ }^{38}$

The ceremonies attached to the person of the Sultan himself, as well as his entertainment, display a sort of decorum which was the privilege of the court. But the court life largely overflowed the very limited circle of the palace and the high officials; it infused the arteries of the small city with the pomp and luxury which are elements of urban life. The hair of the Sultan was thrown into the sea, having been carried in procession to a musical accompaniment; the end of his religious instruction was the object of a ceremony (khatam alQur'an); his marriage was an occasion for festivities. Sultan Abdul Hamid liked to disport himself in a boat: in 1775, when he was about 13 , he made a trip in his perahu kora-kora manned by 74 men; five years later, on several occasions he went out competing with his ministers, with a buffalo and goats or hens as stake. ${ }^{39}$ The coronation and the burial of a Sultan were the occasions for much more important ceremonies in which the whole town participated. A poem composed about 1830 by an inhabitant of Bima describes with a great wealth of detail the funeral of Sultan Abdul Hamid and the enthronement of his successor, Sultan Ismail, in 1817. The author stresses, and we have grounds for believing him, the presence of a considerable crowd during these two events. ${ }^{40}$

Within its limits the court of Bima reproduced some of the pomp of more important sultanates. In 1879 the Belgian naturalist, A. Colfs, described as follows the procession entrusted with bearing the letter of the Governor of Makassar to the palace:

The deputation which arrived to take the letter was composed thus: Right at the very front came a djouroutoulis with two men, followed by a drum and a fife; then came twelve court horses mounted by the adat (the Sultan's council), which pranced into the courtyard of the controleur; here the horses halted and their riders presented their lances

\footnotetext{
${ }^{36}$ Journal of Muh. Djafar.

37 Cf. H. Chambert-Loir, Ceritera asal bangsa jin dan segala dewa-dewa (Bandung: Angkasa-EFEO, 1985), pp. 81-82.

38 This horse, of which the tradition goes back to Sultan Abu'1 Khair Sirajuddin (r. 1640-1682), was led in procession every Friday to be bathed in a river close to this hill. According to the somewhat exotic formula given by Rouffaer (Noorduyn, Bima en Sumbazva, p. 102), the Sultan had commanded "that this horse should be mandied in the kali near the kraton every Friday morning" ("dat dit paard elken Vrijdag morgen in de kali bij de kraton zou gemandi'd worden").

${ }^{39}$ These various events are mentioned in the journal of Muh. Djafar.

${ }^{40} \mathrm{Cf}$. Chambert-Loir, Syair Kerajaan Bima, stanzas 82-217 and 289-487. A description of a more recent ceremony is found in M. A. Bouman, "Toeharlanti. De Bimaneesche sultansverheffing, "Koloniaal Tijdschrift 14, 6 (1925): 710-17.
} 
horizontally with arms extended; then they withdrew; next came a young man wearing a white turban and a long white robe borne by four coulis on a sort of stretcher, resembling an armchair without legs, on which he sat with his legs crossed; on his knees he bore a silver salver covered by a kerchief and entered into the house where the controleur put the letter on the salver for him. This having been accomplished, it was covered by the kerchief and the two ends of a sort of mantle, which was put on the shoulders of the young man. People say that the yellow letter is considered to be the Governor of Célèbes and should the bearer have the misfortune to drop it, he risked being beheaded. The insignia of the Sultan consisting of two red flags waited at the door. These are the same insignia which are thought to be the ancestors of the Sultan. The delivery of the letter was greeted with a salute from 13 cannon fired from the European fort. ${ }^{41}$

Some ceremonies were more imposing than one might imagine. More than one author was astonished by the richness of the costumes of state: for example Asselbergs, who also admired a gun of Turkish origin at the palace: "a weapon entirely encrusted with pure gold and of which I have never seen such a valuable specimen." 42 Among the rare vestiges of the splendors of the palace today one can still admire a collection of weapons including handles of keris and sheaths of gold of very great beauty.

One festival with an undeniably popular character, even though it was linked to the palace, was the ceremony of sirihpuan, which occurred during the celebration of the birth and death of the Prophet Muhammad (the festival of Maulud), which has great significance throughout the whole of the Archipelago. Both Damste and A. Amin give an account of its origin according to a tradition which still remains alive to this day:43 the ceremony was introduced by Malay religious teachers in the middle of the 17th century in order to remind the second Sultan of his pious duties. A pavilion with a pyramidal shape (and with a twotiered roof in the 1928 or 1929 photographs published by Damsté) was constructed from bamboo to represent the cupola which covers the grave of Muhammad at Medina. It was decorated with artificial flowers and contained a copy of the Koran, which the head of the Malay community (the penghulu) presented to the Sultan at the end of the ceremony. The penghulu and the dancers took their places in this construction which the bearers carried from Kampung Melayu to the palace amid dancing and popular rejoicing. In a comparison (rather overhasty) between this ceremony and the funerary feasts in Bali and Celebes, Damste concludes that the sirihpuan was probably the perpetuance, in Muslim guise, of an autochthonous burial rite. Indeed it was for reasons of orthodoxy, it seems, that the ceremony was to be suppressed at the beginning of the $1950 \mathrm{~s}$.

Islam has been an essential component of Bimanese culture since the 17th century, but this is a characteristic which affects the kingdom and even the entire island. It does not seem possible to extract any traits which are specific to the town of Bima, except for a certain concentration of religious education and the gathering of pilgrims at the time of their departure for Mecca. Since the advent of Islamization one new component in this Muslim culture has been the introduction of a literature in Malay. Palace chronicles and literary and historical works were written in Bima; moreover they display evidence of a knowledge of many more original Malay works from the west of the Archipelago. This tradition continued without a break: the chronicles were preserved and recopied; at the time of Sultan Abdul Hamid, in

41 Colfs, Het Journaal van Albert Colfs, p. 20

42 Asselbergs, "Eene reis naar het eiland Soembawa," p. 66.

43 Ahmad Amin, "Sedjarah Bima. Sedjarah pemerintahan dan serba-serbi kebudajaan Bima" (Bima: Kantor Kebudajaan, 1971, stencil), pp. 53-57, 82-86. 
November 1776, "hikayat were read" at the palace, 44 and about 1830 a religious scholar, Khatib Lukman, wrote a poem about the events which had marked his era. ${ }^{45}$

We shall not linger with this literature, the essential aspects of which have already been discussed elsewhere. ${ }^{46}$ It was certainly an appurtenance of the court and of a limited elite, because it is probable that at this period the number of Bimanese who had mastered this degree of Malay would have been negligible. However, the existence of this elite and the creation of a literature in a lingua franca are, in point of fact, two specific features of urban life.

\section{Commerce and State}

The adoption of Malay was bound up with the propagation of Islam; these two phenomena are themselves linked to the commercial network in which Bima was a stopping-place, because the town, the main characteristics of which have just been sketched, and the relative luxury which the nobility enjoyed, were based entirely on commerce. As far back as one can delve into history, Bima was a sufficiently prosperous region for the ships which plied the Archipelago to call there to take on provisions.

Before the 17th century there is no detailed information about the exports of Bima. Between 1624 and 1665 the Dagh Register records in a repetitive fashion the arrival in Batavia, and occasionally in Ambon, of products purchased in Bima. First and foremost among these was rice, but slaves, brazilwood (Mal. kayu sapang; Caesalpinia sappan L., from which a red dye was extracted), wax, sandalwood, tamarind, sulphur, cinnamon, and palm sugar were also included. These registers specifically put Bima in a relationship with Ambon, Banjar, Makassar, Banten, Palembang, and even China. ${ }^{47}$ One item for export, which had perhaps been important before the Islamization, was pork: the Dutch purchased this in Bima in 1619, the same year in which the decisive attack from Makassar brought about the conversion of the realm. ${ }^{48}$

Trade with Makassar around 1660, as it was recorded by C. Speelman, apart from brazilwood, which was resold in Macao, involved different Bimanese products: clothes retailed in Manila and Pasir-Kutai, horses re-exported to Macao, buffalo destined for Aceh, and ganitriljenitri nuts (Elaeocarpus ganitrus Roxb.), used as rosary beads, which were also sold in Aceh. ${ }^{49}$

The relative quantities of the various products exported varied from one epoch to the other. The most important items were brazilwood (sapang) and wax, the monopoly on which the VOC reserved for itself by the way of contracts, while rice, green soya beans (kacang hijau), and onions represented agricultural produce, and horses and buffalo the stockbreeding sector. In the middle of the last century Zollinger added salt, cotton, sugar (both cane and palm), bêche de mer (tripang), swallows' nests ("these are the exclusive property of the Sultan ... [and] are mainly of good, indeed prime, quality"), and goats, as

44 Journal of Muh. Djafar.

${ }^{45}$ Chambert-Loir, Syair Kerajaan Bima.

46 H. Chambert-Loir, "Les sources malaises de l'histoire de Bima," Archipel 20 (1980): 269-80.

47 Dagh Register, passim. On March 7, 1627, was noted the arrival in Batavia of several junks from China, one of them bound for Bima.

48 J. Noorduyn, "Makasar and the Islamization of Bima," BKI 143, 2-3 (1987): 312-42.

49 J. Noorduyn, "De handelsrelaties van het Makassarse rijk volgens de Notitie van Cornelis Speelman uit 1670," Nederlandse Historische Brommen 3 (1983): 96-123. 
well as heavy textiles, buffalo hides, and the dried meat (dendeng) of deer and buffalo, to the former list. Zollinger stresses the "almost incredible number" of horses, trade in which was virtually entirely in the hands of the Arabs. "Someone who has never been to Bima cannot conceive of the number, the strength and the beauty of its horses." Moreover, he also noted the destination of these items; over and above the neighboring states (Dompu, Sumbawa, Makassar, Selayar, and Manggarai), these included Ambon, Timor, Lombok, Bali, Java, and Singapore. ${ }^{50}$ These were the same areas which provided Bima with metals, fabrics, dried fish, tobacco, opium (another monopoly of the Sultan), and slaves.

These 17th and 19th century Dutch documents reveal the importance of the trade of Bima, the source of its prosperity, as well as the geographical extent of its outlets. Earlier than this there is the evidence of Tome Pires, which is of particular interest as it offers a picture of this commercial activity before the intervention of the Europeans. Writing during the second decade of the 16th century Pires also cites among the wealth of Bima: brazilwood, tamarind, horses, slaves, and textiles, to which he adds meat, fish, and gold:

The island of Bima (. . .) is a large island belonging to a heathen king. It has many paraos and many foodstuffs in great plenty; it has meat, fish; it has many tamarinds; it has a great deal of brazil, which they take to Malacca to sell, and they go there from Malacca for it because it sells well in China, and the Bima brazil is very thin. It is worth less in China than that of Siam, because that from Siam is thicker and better. Bima also has a large number of slaves and many horses which they take to Java. This island has trade. They are swarthy people with straight hair. This island has a number of villages, and also many people and many woods. People who are going to Banda and the Moluccas call here, and they buy many cloths here, which sell well in Banda and the Moluccas. This island has some gold. Javanese cashes are current here. ${ }^{51}$

Thus Bima was clearly situated on the route which linked Malacca to the Moluccas. Pires characterizes the indigenous trade in the following fashion: "as they have little capital and the sailors are slaves, they make their journeys long and profitable, because from Malacca they take merchandise to sell in Java, and from Java merchandise to sell in Bima and Sumbawa, and from these islands they take cloth for Banda and the Moluccas, and that which they have kept in reserve from Malacca." 52

The commercial activity of Bima therefore plainly predated the European sources which described it in some detail. Other evidence proves the existence of a central authority in Bima, and, consequently, the development of the capital even further back in time. First of all there are the archaeological remains ${ }^{53}$ which, combined with the mention of Bimanese toponyms in historical Javanese texts, demonstrate the existence of political centers in the eastern part of Sumbawa and the Hindu-Javanese influence exercised there, at the latest in the middle of the 14th century. Van Naerssen has already noted that Bima (Bhima) was mentioned in the Nagarakertagama (14.3.4), as are Taliwang, Dompu, Sape, and Sangeang, 54 that the date of the expedition of Majapahit against Dompu was given in the Pararaton,

\footnotetext{
50 Zollinger, Verslag van eene reis, pp. 101-109.

51 Tomé Pires, The Suma Oriental of Tomé Pires ... Translated and edited by A. Cortesao 2 vols. (London: Hakluyt Society, 1944) 1: 203.

52 Ibid., p. 220.

53 These remains have been principally described by Rouffaer (cf. F.H. van Naerssen, "Hindoejavaansche overblijfselen op Soembawa,"TAG [2nd series] 55[1938] and Noorduyn, Bima en Sumbawa). Others have been discovered since and have been recorded by the Archaeological Service of Indonesia (Puslit Arkenas).

54 Cf. Th. Pigeaud, Java in the 14th Century, 5 vols. (The Hague: Nijhoff, 1960-1963), 3: 17.
} 
namely 1279 S, or AD 1357,55 and finally that the novel Rangga Lawe mentions "the excellent horses acquired at Bhimakore," a name which combines the two toponyms Bima and Kore, as was also the case in Pigafetta.

The second type of evidence relevant to this early period is found in the dynastic myth of Bima, the most complete version of which is found in its Malay edition entitled "History of the Origins of Jinns and dewa-s." 56 This "history" begins with the creation by Allah of the first jinn and the first man. The genealogy of the jinns merges into the five Pandawa brothers who reign over the island of Java, while the human line leads to Iskandar Zulkarnain, to whom the Islamization of the countries of the East and the West is attributed. It is from the second of the Pandawas, Bima, that the Bimanese dynasty, which numbered 11 kings before the first Sultan (Abdul Kahir, who reigned at the beginning of the 17th century) issued.

It would be vain to attempt to estimate the antiquity of this dynasty by attributing a hypothetical duration to the reigns of these pre-Muslim rulers. On the other hand, analysis of the myth allows us to determine with some certainty that this is the outcome of a local tradition reshaped at the time of the Hindu realm, before being transformed anew during the process of Islamization. Or, to put it another way, some of the sparse archaeological remains in the vicinity of Bima do indeed tally well with the existence of a Hindu kingdom, of which Bima had also been the capital.

A recent archaeological discovery allows us to push back the first wave of Hinduization to a much earlier date. A rupestral Shivaite site, situated on the western shore of the mouth of the Bay of Bima, known as Wadu Paa (Malay Batu Pahat, "chiseled stone"), was noted by the Dutch Resident of Bima in 1862.57 Subsequently it was studied and described by Rouffaer in 1910.58 Only about a dozen or so years ago a new site, which perhaps was only part of the previous one, was discovered to the north of it: this contains, amongst other things, a brief inscription in Pallava script and most probably composed in Sanskrit. The brevity and the erosion of this inscription make its palaeographic examination particularly difficult; nonetheless, the most cautious estimate is that it is not later than the 9 th century. ${ }^{59}$

It is not possible to assert that either the town or the kingdom of Bima existed at this period, but it is clear that the Bay of Bima was already a place of call on the trade route which brought Hindu merchants from Java to the Moluccas. The site of Wadu Paa is situated on a creek very close to a fresh water source; it was thus an ideal place for a sheltered, easily accessible watering place. Following the example of indigenous merchants, the Europeans made use of it as well: in 1847 (i.e. before the Shivaite cult site had been identified), Zollinger speaks of a "so-called Portuguese cave," 60 and in 1910 Rouffaer could still make out Dutch graffiti dated 1768 and 1783.61

55 Cf. J. Brandes, Pararaton (Ken Arok), of het boek der koningen van Tumapel en Majapahit (2nd ed. Batavia/The Hague: VBG 52, 1920), p. 158.

56 Chambert-Loir, Ceritera Asal.

57 H. Holtz, "Oudheden op Soembawa," TBG 11(1862): 157-58.

58 Rouffaer's notes have been published by Van Naerssen, "Hindoejavaansche overblijfselen," pp. 93-95 and by Noorduyn, Bima en Sumbawa, pp. 92-95.

59 An Indonesian epigrapher first estimated that it could go back to the 6th or 7th century (cf. Chambert-Loir, Ceritera asal, p. 91). On the basis of characters similar to certain types from East Java, Prof. de Casparis (personal communication, August 1988) prefers to date the inscription to the 10th-12th centuries.

60 Zollinger, Verslag van eene reis, p. 39.

61 Noorduyn, Bima en Sumbawa, p. 95. 
Archaeological excavations would perhaps allow an evaluation of how long the Shivaite site was used. For the time being, we do not know whether it was a religious site from its foundation right up to the era of Islamization. It is even more interesting to see that its status as a privileged, indeed sacred, site has been perpetuated up to our own day and that the site has been somehow incorporated into the urban complex of Bima.

In January 1785, when Sultan Abdul Hamid set sail for Manggarai with 50 ships, he first called at Wadu Paa. ${ }^{62}$ And once again, when he set off to Makassar in April 1792, he spent six days at Wadu Paa while "his orchestra played continuously." 63 Up to the present day, as Rouffaer already confirmed in 1910, the site is still covered with recent inscriptions daubed in various languages. The Chinese of Bima, who never had a klenteng in the town, go there to celebrate their ceremonies. Bimanese Muslims visit there to make vows and to give thanks when these are realized. Finally, newly built ships from Bima, or those which have returned safe and sound from a long voyage, to Java for example, call at the creek of Wadu Paa to hold a selamatan (propitiatory meal or thanksgiving), which is accompanied by the sacrifice of a goat or buffalo.

The perenniality of this religious site is one of the tangible signs of the antiquity and continuity of Bimanese history. An area rich in commercial products, situated on the trade route between the farthest poles of the Indonesian Archipelago, the eastern part of the island of Sumbawa derived its prosperity from commerce. This was probably what favored the concentration of power and gave rise to a Hindu state. It would be useful to study to what extent the flow of commerce was the vehicle for the Javanese, Malay, and Makassarese influences which became the model for Bimanese society in the evolution of a court culture, the manifestations of which are known to us starting from the beginning of the 17th century. Whatever the circumstances, this commercial activity and the centralization which came in its wake, led to the codification of a specifically urban society, which was very original on account of certain aspects of its organization, and at the same time comparable on many points to other towns in the region.

Translated by Rosemary Robson

62 Journal of Muh. Djafar.

${ }^{63}$ Chambert-Loir, Syair Kerajaan Bima, pp. 189-90. 